\title{
The Scope for Mobilising Public Opinion against Corruption: THE ATtitudes OF KWAZulu-Natal University STUdENTS
}

\author{
Geoff Harris
}

Department of Public Management \& Economics, Durban University of Technology

Alexander Dawid van der Merwe

Department of Economics Durban University of Technology

Accepted: November 2011

\begin{abstract}
The aim of this study is to ascertain perceptions of public sector corruption that university students, as potentially influential members of society, hold. The study is based on a purposive sample of 509 first- and second-year university students. Descriptive and non-parametric bivariate analysis suggests that students overwhelmingly regard public sector corruption as an important issue. In addition, there appear to be remarkable degrees of consensus as to what actions are perceived as corrupt even if there is evidence of mismatches between students' beliefs and likely actions. At least some of this dissonance may be explained by the finding that respondents' corruption perceptions are biased by gender and ethnicity. These are challenges that programmes aimed at inspiring mass public opinion to join the fight against corruption may have to address.
\end{abstract}

Key words: corruption, graft, public sector corruption, anti-corruption measures

JEL: HOO, ZOO

\section{1}

\section{Introduction}

There is increasing awareness of the costs of corruption as documented in a growing international literature. The Country Corruption Assessment Report (CCAR) (Anon., 2003) identifies the following evils of corruption: it hamstrings economic development, interferes with good governance, erodes stability of and trust in - government', damages the ethos of democratic government and has considerable social and economic costs

Anti-corruption initiatives are a common, and politically expedient, response to perceptions of high and rising levels of corruption. The latest Corruptions Perceptions Index (Anon., 2010a) ranks South Africa at number 54 out of 178 countries, where 1 is the least corrupt country. South Africa's corruption rating in terms of Transparency International's Corruption Perceptions Index (CPI) has deteriorated consistently from 5.1 in 2007 to 4.5 in 2010
(Anon., 2010a). Van der Merwe (2006) finds that corruption is perceived by public servants to be widespread throughout KwaZulu-Natal provincial and national government departments.

Official concern about corruption levels in South Africa and how to tackle it gained momentum in 1999 with the launch of the National Anti-Corruption Initiative and the creation of the National Anti-Corruption Forum in 2001 (Baqwa, 1999). Following the implementation of these and, subsequently, a host of other measures aimed at reducing corruption the question must be asked: how effective are they if South Africa has become a more corrupt country in recent years? A heightened national sensitivity towards corruption is evident in the National Planning Commission's (2011a) Diagnostic Report in which it identifies corruption as one of nine major challenges facing the country.

This paper explores, on a case study basis, the attitudes of university students in KwaZuluNatal to aspects of public sector corruption and 
also discusses the possible implications of the corruption perceptions of young citizens for the local fight against corruption. It proposes that South Africa's general anticorruption approach, which is essentially founded on a mix of principal-agent theory and institutional perspectives, is flawed in at least three respects. Firstly, the principal-agent model depends on the principal for implementing reforms and this is a weakness if one considers that there may be several principals each with incoherent objectives and diverse interests (Andvig, Fjelstad, Amundsen, Sissener \& Soreide, 2000). Secondly, the principal-agent notion that it is invariably the principal's objective to reduce corruption, and that the principal is therefore not corrupt, may not always be the case. Finally, anticorruption measures can have no significant effect, may find no traction, if there is no real belief in the imperative of acting ethically and morally. There can be no effective monitoring of corruption if society does not perceive certain actions as corrupt or discounts their true cost (Olken, 2007).

This article probes the possibility that the notions university students, as potential community leaders, have of what constitutes ethical and moral behaviour may be highly variable so as to confound efforts to harness mass public opinion in the local fight against graft. The discussion brings to the fore the issue of integrity and ethics education in South African schools and institutions of higher learning as a vital, although evidently neglected, component of local corruption control. The notion of introducing formal ethics education at school and university level is not without precedent (Van der Merwe, 2004). However, such programmes would need to be sensitive to society's perceptions of corruption.

The study considers the following questions:

1. How serious do university students perceive the problem of public sector corruption to be?

2. What actions do students believe constitute corrupt behaviour?

3. Are students' perceptions of what constitutes corruption influenced by factors such as gender, ethnicity and religious beliefs?

The answers to these questions may shed more light on the bigger question of how best to mobilise public opinion in the fight against local public sector corruption.

Section 2 reviews some of the literature on corruption; Section 3 explains the study's methodology, Section 4 discusses the analysis and results and Section 5 concludes.

\section{2}

\section{Review of the literature}

\subsection{Defining corruption}

The many possible varieties of corruption render it a difficult-to-define and complex phenomenon so that it becomes problematic to distinguish corruption from other forms of social exchange. For the purposes of this discussion corruption is regarded to be:

-...behaviour which deviates from the formal duties of a public role because of private-regarding (personal, close family, private clique) pecuniary or status gains; or violates rules against the exercise of certain types of private regarding influence. This includes behaviour such as bribery (use of a reward to pervert the judgment of a person in a position of trust); nepotism (bestowal of patronage by reason of ascriptive relationship rather than merit); and misappropriation (illegal use of public resources for private gain). (Nye, 1967:419).

\subsection{Corruption: predisposing factors}

The international literature suggests that, historically, corrupt behaviour may be influenced by a range of variables: natural resource availability, culture/ethnicity, masculinity, uncertainty, religion, power distance, inequity, the quality of public institutions, size of government, level of development, market regulation, the market system and economic conditions.

Thus some evidence has been reported that population size and natural resource wealth appear to be positively correlated with the incidence of bribery (Cartier-Bresson, 2000; Andvig et al., 2000). Other studies report that corruption appears to be influenced by attitudes, paradigms and values deeply rooted in the culture of certain populations (Husted, 1999; Getz \& Volkema, 2001). Several studies record that males are more likely than women 
to act corruptly (Lambsdorff, 1999; Getz \& Volkema, 2001; Bowman \& Gilligan, 2008). Paldam (2001) found that certain religions may be more tolerant of corruption and that religious diversity reduces the incidence of corruption.

Husted (1999) proposed that corruption is tolerated more readily in high power distance (paternalistic) cultures than in low power distance cultures. The quality of public institutions such as government offices, the judiciary and the media have been associated with corruption levels (Cartier-Bresson, 2000). Lambsdorff (1999) notes that corruption levels have been shown to increase when government regulation imposes a heavy burden on business competitiveness.

Corruption is more likely to be exposed in developed countries precisely because their public institutions such as the press and other media tend to be more established. This is apart from the consideration that economic development increases the spread of education, literacy and depersonalized relationships, all of which act to constrain graft (Andvig et al., 2000). There seems to be some consensus that the prospect of economic adversity heightens the appeal of corruption (Getz \& Volkema, 2001; Razafrindrakoto \& Roubaud, 2003).

\subsection{Nuances of corruption in South Africa}

The values and norms of a particular society can be expected to inform its attitudes to corruption. South Africa has a complex politico-economic history and this affects the genesis and character of local corruption. Spencer (2001) suggests that South Africans seem to have difficulty distinguishing between legality and morality. He proposes that morality is concerned with objective principles such as duty, obligation and fairness which should be universally desirable. Thus legality deals with what one can get away with while morality deals with what one should not attempt to avoid.

Bauer (2000) asserts that the aspect of racial entitlement enshrined in the philosophy of apartheid contributed to the development of a culture of corruption. Within this system, some officials had become disillusioned in their efforts to serve the apartheid policy of mass removals and resettlements of people. Such officials would thus help themselves to the large amounts of funds allocated to these projects which, in many instances, held no appeal for them and were probably considered in any case to be wasteful expenditure.

Apartheid thus perverted not only the morals of its mandarins but also those on whom it was inflicted. Kaunda (2001) proposes that apartheid left behind a legacy of a serious breakdown of morals in South African society. She suggests that the results of this collapse can be seen in, among other instances, diminishing parental control of children, a lack of respect for authority and the rule of law and high and rising levels of crime and corruption. Mthombothi (2000) agrees that apartheid fostered moral depravity and that all South Africans have been corrupted by it. He proposes that South African society, generally, is tolerant of dishonest and corrupt conduct, that cheating is ubiquitous whether in the form of tax evasion, illegal transfers of money out of the country or dubious business practices. Indeed it seems that the spectre of corruption lingers on in the post-apartheid era. Makhanya (2003) confirms that South African society is apparently becoming increasingly apathetic about the phenomenon of graft in seeming to accept that this is inevitable in government.

In South Africa's new political dispensation corruption appears to have some subtly unique characteristics. A common thread linking many of the transactions that have been labelled as corrupt after the advent of democracy in 1994 is that they have drawn openly on the privilege of political office or connections in government (Van der Merwe, 2004; Lund, 2010). Considerable evidence has been cited of corrupt transactions between government and favoured groups or cliques (Haffejee, 2001; Ayoob, 2003). Hogg (2011) notes that many appear to regard this "reciprocity" between government and select beneficiaries as due reward for loyal support. He observes, furthermore, that the arrangement may enjoy currency as a tool of economic empowerment.

Transactions concluded by some public officials verge on blatant criminality. It is common cause that South Africa has a high crime rate which fact Rautenbach (2000) 
proposes is a characteristic of a nonconformist society. Nonconformist societies are typically heterogeneous and display large social cleavages in terms of language, ethnicity, religion, education levels and income. Such societies - South Africa being a good example in Rautenbach's estimation - tend to have high levels of disorder, indiscipline and disregard for the law. It is not inconceivable that, in such an environment, there might be a nexus between crime and corruption.

The capacity to corrupt public processes provides significant regulatory advantages by protecting criminal enterprise (Shaw, 1998; Baqwa, 1999). Thus crime and corruption thrive in a symbiotic relationship. This is an intuitively appealing notion if one considers, for instance, the corruption charges that were brought against South Africa's erstwhile Police Commissioner (Anon., 2008) and the criminal charges against the wife of South Africa's State Security Minister (Anon., 2010b). Organized crime within the country is reported to be rife (Irish, 2003; Hartley, 2009) and it appears that corruption in commerce, law enforcement and in other government departments perpetuates this situation (Irish, 2003). Indeed, President Zuma (2009, 2010) has, in two consecutive state-of-the-nation addresses felt it necessary to pledge greater efforts and resources to combating corruption in the public sector.

Survey results suggest that a decline in ethics and morals is the most commonly cited cause of corruption in South African society in general (Camerer, 2001; Van der Merwe 2006). The Country Corruption Assessment Report (Anon., 2003) claims evidence of a decay in moral values in general within society. Landman (2000) argues that South Africa is undergoing a moral and ethical crisis as a result of centuries of social engineering of the worst kind. He suggests that this circumstance has been compounded by the country's sudden political changes commencing in 1994 with all its attendant insecurities and new institutions, unemployment and other factors such as HIV and Aids. Greed and moral dislocation, symptoms of distorted values, have also been identified as major causes of local crime and corruption (Camerer, 2001; Rauch, 2005; Van der Merwe, 2006).

\subsection{A note on South Africa's general anticorruption approach}

The character of corruption and its likely causes should inform efforts to combat it Historically, there appear to be three distinct approaches to controlling corruption (Doig \& Riley, 1998): those based on economic analyses, those founded on mass public opinion or civic culture perspectives and those informed by institutional viewpoints. The institutional approach to corruption control emphasizes the strengthening of institutions such as anti-corruption agencies or functions and procedures within organisations such as registers of interest and codes to delineate the expectations the public has of officials. Mass public opinion perspectives examine the social or cultural context of corruption and suggest mass attitudinal change or civic awareness anti-corruption strategies. Economic analyses of corruption generally mostly prioritize the principal-agent approach which is rooted in neoclassical economic theory and has been used extensively by the World Bank.

The debate on the effectiveness of anticorruption strategies has changed markedly since the 1980s. The development agenda of the 1990s focused on developing market economies and liberal democratic systems (Riley, 1998). Within this agenda, the new context of corruption was conditioned by two assumptions. The first is that public sector corruption will be reduced if the size of the state is reduced. The second is that a move to liberal pluralist politics, a freer press and the creation of other independent institutions (the judiciary for instance) will reduce corruption by making it vulnerable to exposure. Riley noted that the policy agenda of the 1990s assumed a limited, legitimate and honest state which in fact may not be the case when the state sector is swollen, corrupt and inefficient and individual and group interests have priority over the public good.

Modern corruption control techniques appear to be strongly informed by principal-agent/ incentive theory. According to this philosophy, the principal is assumed to be honest while the agent/official and client are motivated by selfinterest. Thus any decision by the agent and client to behave dishonestly is based on calculations of potential personal gains and 
losses that may result from these actions. Accordingly, measures designed to constrain corruption include reducing opportunities for exacting economic rents and the exercising of monopoly power by means of deregulation and privatization. Furthermore, administrative reform may be aimed at reducing officials' discretion and also demanding greater accountability from public servants. The building up of institutions such as auditing and accounting units, legal reforms and encouraging public oversight through parliament and a more vibrant civil society are also core components of modern corruption control.

Van der Merwe (2004) notes that South Africa has in place most of the constituent elements of a sound anticorruption system. This includes a comprehensive and practical legislative framework as well as various anticorruption and law enforcement agencies. Mechanisms to report corruption are in place as well as strong frameworks for financial, procurement risk and human resource management. Van der Merwe finds, in spite of this, that local anticorruption initiatives have evidently had no significant impact on KwaZulu-Natal public sector corruption levels. He argues that this state of affairs can be blamed on, amongst other things, a failure to implement existing measures and strategies due to a lack of resources and political will. Thus the institutions charged with keeping corruption in check (institutional approach to corruption control) lack the capacity to do so effectively. Woods (2011) argues that this failure of government organisations to properly apply systems creates opportunities for would-be perpetrators of corruption. The reality of corrupt principals, whose activities will be further shrouded by a veil of state-sanctioned secrecy if the mooted Protection of Information Bill is passed in undiluted form, suggests that the principal-agent approach to corruption control can enjoy only limited success.

The CCAR (Anon., 2003) identifies the following causes of corruption within South Africa's private and public sectors: inefficient control mechanisms, insufficient anticorruption training, greed, poverty and the decay of moral societal values. Its anticorruption recommendations are correspondingly set out under five headings: enhancing institutional capacity to fight corruption, improving management policies and practices in the public service, slicker reporting of corruption, creating partnerships in the fight against corruption and promoting ethics and civic awareness. This study is particularly interested in the prospects that the last three recommendations hold for corruption control insofar as they hint at the need to mobilise mass public opinion more effectively in the fight against corruption.

\section{3}

\section{Research method}

This study employed a purposive sampling design in that it is based on a survey of firstand second-year students enrolled in particular economics and business/administration classes at both the Durban University of Technology (DUT, Pietermaritzburg) and University of KwaZulu-Natal (UKZN, Durban) in 2010. The choice of sample was influenced by the consideration that university students are likely to become leaders and opinion makers (Anon., 2011), citizens who are most likely to demand accountability in respect of curbing corruption. The relatively large sample size $(n=509)$ offers a measure of confidence that the sample is reasonably representative of the population from which it was drawn. The mainly nominal and ordinal nature of the survey data, dictated the employment of non-parametric inferential analytical techniques together with some descriptive statistical analysis.

The survey instrument employed to gather the data comprises a short biographical section with four questions relating to respondents' gender, age, ethnicity and religious beliefs. The literature generally confirms that gender (Bowman \& Gilligan, 2008), ethnicity (Getz \& Volkema, 2001) and religion (Paldam, 2001) have all been implicated in the corruption perceptions that individuals hold. The balance of the questionnaire (totalling sixteen rating scale items) solicits the views, perceptions and attitudes of respondents to aspects of public sector corruption. The study, in seeking to construct meaning and knowledge from respondents' perceptions, draws on the qualitative approach to research design. Within 
this framework research outcomes are neither totally objective nor unquestionably certain (Henning, Van Rensburg \& Smit, 2004).

The survey instrument was duly piloted and refined before it was administered. Practical considerations dictated a survey technique in which accessible first- and second-year economics/administration classes, with the permission of lecturers, were subsequently surveyed at both campuses during scheduled lectures. Respondents were generally able to complete the questionnaire, on average, in about 10-15 minutes.

\section{4}

\section{Analysis and discussion}

The first part of the research collected demographic data from the respondents and asked five questions about their attitudes towards corruption in South Africa.

\subsection{Sample characteristics}

Of the 509 respondents, 53.8 per cent are females and 46.2 per cent are males. Their mean age was 20.2 years, with 79 per cent aged 19 to 21 years. In terms of ethnicity, 318 of the respondents (62.4 per cent) are black and 168 (33.0 per cent) are Indian, with small numbers of whites (12) and coloureds (11). As to the importance of their religious beliefs, 95 per cent said that these were at least important (62.2 per cent $=$ very important and 32.8 per cent $=$ important) to them; the pilot survey indicated that asking respondents for their particular religion or denomination was problematic and so these were not sought in the main survey.

\subsection{Perceptions of the seriousness of local public sector corruption}

Respondents were asked 'How serious an issue do you think corruption is in South Africa these days?' Almost all respondents regarded it as either very serious ( 73.7 per cent) or serious (23.4 per cent). In response to a question asking them to compare levels of corruption now compared with three years ago, almost half (47.2 per cent) thought it was much worse and 31.8 per cent that it was a bit worse. This result would seem to corroborate the trend of perceived worsening corruption in the three years leading up 2010 highlighted by Transparency International's CPI.

Three questions were asked about perceptions of corruption among public servants, politicians and by the president on a scale ranging from 10 (extremely corrupt) to 0 (not at all corrupt). Public servants were given a mean score of 8.0, somewhat less than that given to politicians (8.6). Both are towards the very corrupt end of the scale. The president was better regarded, with a mean score of 6.8. It was intended to cross tabulate these and later responses by gender, age, ethnicity and importance of religion. However, the narrow age range and the importance of their religious beliefs to almost all respondents meant that these two variables could not be used for cross tabulation purposes. The small numbers of whites and coloureds in the sample meant that ethnic comparisons had to be restricted to those between blacks and Indians.

There were no significant gender differences concerning respondents' ratings of the seriousness of corruption, whether corruption had become more of a problem and their ratings of the corruptness of politicians, public servants and the president. It is notable, though, that Indian respondents were significantly more likely than black respondents to regard corruption as very serious and to have become much worse. A strong majority of both groups, it should be noted, regarded it as very serious and becoming much worse. Indian respondents perceived higher corruption among politicians and public servants than did black respondents and rated the president at 8.1 on the corruption scale compared with 5.9 by black respondents. These apparent ethnic differences will be examined further.

\subsection{What is perceived as 'corrupt' behavior?}

Individuals' perceptions of the extent of corruption must logically be informed by what they regard to be corrupt behavior. The uniformity, or otherwise, of corruption perceptions has implications for monitoring and policing corrupt actions (Olken, 2007). Thus, if behavior is overwhelmingly considered to be corrupt, it may be easier to detect and the policing of such actions is likely to enjoy popular support. Such a development, on the 
back of galvanized mass public opinion, could be expected to strengthen South Africa's fight against public sector graft.

The second part of the research involved posing 10 short scenarios (these are listed in the left hand column of Table 1) and asking two questions of each: first, whether the respondent regarded the behaviour described as corrupt, with four options running from "very corrupt" to "not at all corrupt", plus a category for those who were unsure; and second, whether the student would engage in the activity, with responses running from "definitely not" to "definitely yes", with a "don't know" category. The results are reported in Tables 1 and 2 respectively.

Many of the scenarios drew on cases of possible corruption reported in the South
African media during 2009 and the early part of 2010. Prominent among these were reports of tendering irregularities, of inflated claims for travel expenses by politicians, of public servants engaging in private business work during office hours and of close relations between politicians and public servants on the one hand and business people on the other. It is likely that students had some knowledge of these examples and of the explicit or implicit messages in the media about them but this does not, in our view, lead to any concerns about our scenarios. These were intended to uncover student attitudes towards such behaviours and their possible future involvement in them. At the same time, while we have no way of knowing that students answered honestly, we see little reason for them to lie.

\section{Table 1}

Perceptions of the degree of corruption involved in the 10 scenarios (per cent)

\begin{tabular}{|c|c|c|c|c|c|}
\hline Scenario & $\begin{array}{l}\text { Very } \\
\text { corrupt }\end{array}$ & $\begin{array}{l}\text { Fairly } \\
\text { corrupt }\end{array}$ & $\begin{array}{l}\text { A little bit } \\
\text { corrupt }\end{array}$ & $\begin{array}{c}\text { Not at all } \\
\text { corrupt }\end{array}$ & Unsure \\
\hline $\begin{array}{l}\text { 1. A businessman pays R1.2 million to a politician to } \\
\text { encourage the politician to award a major } \\
\text { government contract to him }\end{array}$ & 86.1 & 10.6 & 1.6 & 0.4 & 1.4 \\
\hline $\begin{array}{l}\text { 2. Correct tender processes for a local government } \\
\text { road building project are not followed; rather, the } \\
\text { contract is simply given to a company, with no } \\
\text { particular experience, owned by friends of the most } \\
\text { powerful councillors }\end{array}$ & 79.3 & 14.8 & 2.2 & 1.0 & 2.8 \\
\hline $\begin{array}{l}\text { 3. A government official arranges for his sister to get } \\
\text { a job (for which she is qualified) in his department } \\
\text { without having to go through the normal application } \\
\text { and selection procedures }\end{array}$ & 42.5 & 34.2 & 19.0 & 3.5 & 0.8 \\
\hline $\begin{array}{l}\text { 4. A politician makes sure that a lot of public works are } \\
\text { carried out in his own community area, which } \\
\text { means that other communities are neglected. }\end{array}$ & 47.9 & 30.3 & 15.5 & 3.5 & 2.7 \\
\hline $\begin{array}{l}\text { 5. A public servant who travels a lot as part of her } \\
\text { work submits claims for reimbursements which are } \\
\text { far above the real cost to her }\end{array}$ & 44.4 & 33.1 & 13.8 & 2.9 & 5.7 \\
\hline $\begin{array}{l}\text { 6. A public servant spends a number of hours of his } \\
\text { work time each week running his private business } \\
\text { activities }\end{array}$ & 38.2 & 32.4 & 18.7 & 7.2 & 3.6 \\
\hline $\begin{array}{l}\text { 7. A traffic policeman asks a motorist for R } 100 \text { in order } \\
\text { for the motorist not to be fined for a traffic offence }\end{array}$ & 73.4 & 20.0 & 5.2 & 1.1 & 0.2 \\
\hline $\begin{array}{l}\text { 8. A cleaner for a university earns R1000 per month } \\
\text { from her job. She takes home cleaning fluid and } \\
\text { other small items which she sells to supplement her } \\
\text { income - by about R30 per month }\end{array}$ & 25.8 & 31.9 & 33.3 & 7.9 & 1.1 \\
\hline $\begin{array}{l}\text { 9. Most teachers in a rural school do not come to work } \\
\text { on Fridays }\end{array}$ & 56.1 & 21.8 & 10.6 & 4.5 & 6.9 \\
\hline $\begin{array}{l}\text { 10. A business firm makes a substantial donation to the } \\
\text { ruling political party each year. The firm doesn't } \\
\text { have particular plans but hopes that they will be } \\
\text { regarded well by the government in the future }\end{array}$ & 30.3 & 26.8 & 15.7 & 18.1 & 9.1 \\
\hline
\end{tabular}


Table 1 indicates that all 10 scenarios were judged to be corrupt or fairly corrupt by half or more of the respondents. The responses can be classified into three groups.

1. Scenarios 1,2 and 7 were rated as very corrupt or fairly corrupt by over 90 per cent of respondents

2. Scenarios 3, 4, 5, 6 and 9 were so rated by 70-79 per cent of respondents

3. Scenarios 8 and 10 were so rated by 57 per cent of respondents.

The first group, comprising direct monetary bribes and illegal tender decisions, represents classic corrupt behaviour whereas there is more to consider in the scenarios of the second group. Scenario 3, for example, involves a possible conflict between interfering with a job selection process and helping a relative. It is possible that respondents found the two scenarios in the last group difficult to categorise. One is theft, albeit of a low level, while the last concerns the relationship between government and business and the responses may involve judgements about the appropriateness of this relationship rather than corruption as such.

The second question - whether the respondent would engage in the activity - was asked to determine whether respondents' anticipated behaviour matched their opinion concerning the corruptness of that behaviour. The term "dissonance" is used to describe a disconnection between beliefs and behaviour. The results are presented in Table 2.

Table 2

Willingness to engage in the activity involved in the 10 scenarios (per cent)

\begin{tabular}{|c|c|c|c|c|c|}
\hline $\begin{array}{c}\text { Your possible response in such a } \\
\text { situation }\end{array}$ & $\begin{array}{l}\text { Definitely } \\
\text { not }\end{array}$ & $\begin{array}{l}\text { Probably } \\
\text { not }\end{array}$ & $\begin{array}{l}\text { Probably } \\
\text { yes }\end{array}$ & $\begin{array}{l}\text { Definitely } \\
\text { yes }\end{array}$ & $\begin{array}{l}\text { Don't } \\
\text { know }\end{array}$ \\
\hline 1. Would you pay a politician? & 51.4 & 21.5 & 15.7 & 3.3 & 8.1 \\
\hline $\begin{array}{l}\text { 2. Would you agree to irregular tendering } \\
\text { practices? }\end{array}$ & 72.2 & 19.4 & 4.3 & 1.4 & 2.7 \\
\hline $\begin{array}{l}\text { 3. Would you get your sister a job without } \\
\text { going through the normal procedures? }\end{array}$ & 36.0 & 27.0 & 27.2 & 4.7 & 5.1 \\
\hline 4. Would you favour your own community? & 45.1 & 23.9 & 19.0 & 3.4 & 8.6 \\
\hline 5. Would you inflate your travel claims? & 42.0 & 30.0 & 17.2 & 3.4 & 7.4 \\
\hline $\begin{array}{l}\text { 6. Would you run your private business } \\
\text { from work? }\end{array}$ & 38.1 & 32.2 & 19.9 & 3.8 & 6.1 \\
\hline 7. Would you ask for a bribe? & 66.5 & 18.7 & 9.2 & 3.1 & 2.5 \\
\hline 8. Would you take small items from work? & 32.0 & 28.0 & 29.0 & 6.3 & 4.7 \\
\hline $\begin{array}{l}\text { 9. Would you stay away from school on } \\
\text { Fridays? }\end{array}$ & 56.1 & 21.8 & 10.6 & 4.5 & 6.9 \\
\hline 10. Would you donate to a political party? & 34.9 & 27.4 & 20.5 & 7.3 & 9.8 \\
\hline
\end{tabular}

Table 1 shows that the average proportion of respondents who rated a scenario as very or fairly corrupt was 78.7 per cent while Table 2 shows that an average of 72.4 per cent said that they definitely or probably would not perform the relevant action themselves. This mismatch indicates the possibility of some dissonance and the importance of disaggregating the responses. Notwithstanding this, it appears that respondents' judgements of the actions of others are strongly correlated with their own likely actions in similar circumstances. Indeed, Spearman's bivariate correlation coefficients in all cases are positive and significant $(\mathrm{p}=$ $0.000<0.01,2$-tailed). This overall consistency suggests a firm foundation on which to base ethics and integrity training.

\subsection{Are corruption perceptions influenced by demographic characteristics?}

It would be helpful for the purposes of harnessing mass public opinion into the anticorruption fight to know what factors may influence individuals' views as to what they perceive to be corrupt behavior. As far as demographic characteristics are concerned females were significantly more likely than males to regard scenarios 4 (favouring your own community) and 6 (running a private 
business from work) as corrupt behaviour. They were also significantly less likely to say that they would probably or definitely engage in the behaviour outlined in six of the scenarios $-1,4,5,6,7$ and 10 (Table 3). Indians were more likely than Africans to regard scenarios 3, 5, 6 and 9 as corruption. African students were significantly more likely than Indian students to say that they would probably or definitely engage in the behaviours outlined in five of the scenarios: 1 and 3-6 (Table 4).

Table 3

Perception of activity being corrupt and being willing to engage, by gender (rounded to the nearest per cent)

\begin{tabular}{|l|c|c|c|c|}
\hline \multicolumn{1}{|c|}{ Hypothetical scenario } & \multicolumn{2}{c|}{ Corrupt } & \multicolumn{2}{c|}{ Engage } \\
\cline { 2 - 5 } & Male & Female & Male & $13^{* *}$ \\
\hline 1. Pay a politician & 99 & 97 & 27 & 5 \\
\hline 2. Irregular tendering practices & 96 & 97 & 7 & 28 \\
\hline 3. Get your sister a job & 97 & 94 & 36 & $17^{* *}$ \\
\hline 4. Favour your own community & 89 & $97^{* *}$ & 28 & $16^{* *}$ \\
\hline 5. Inflate your travel claims & 90 & 92 & 26 & $21^{* *}$ \\
\hline 6. Run business from work & 84 & $93^{* *}$ & 27 & $8^{*}$ \\
\hline 7. Ask for a bribe & 99 & 99 & 17 & 31 \\
\hline 8. Take small items from work & 89 & 93 & 41 & 8 \\
\hline 9. Stay away from school on Fridays & 85 & 92 & 8 & 8 \\
\hline 10. Donate to political party & 69 & 76 & 33 & $23^{* *}$ \\
\hline
\end{tabular}

${ }^{*} p<0.05,{ }^{* *} p<0.01$

Note: Chi-square test results are available from the authors on request.

\section{Table 4}

Perception of activity being corrupt and being willing to engage, by ethnic group (rounded to the nearest per cent)

\begin{tabular}{|c|c|c|c|c|}
\hline \multirow{2}{*}{ Hypothetical scenario } & \multicolumn{2}{|c|}{ Corrupt } & \multicolumn{2}{|c|}{ Engage } \\
\hline & African & Indian & African & Indian \\
\hline 1. Pay a politician & 97 & 100 & 25 & $11^{* *}$ \\
\hline 2. Irregular tendering practices & 94 & 100 & 9 & $1^{*}$ \\
\hline 3. Get your sister a job & 94 & $98^{\star *}$ & 37 & $25^{\star *}$ \\
\hline 4. Favour your own community & 92 & 98 & 25 & $17^{*}$ \\
\hline 5. Inflate your travel claims & 89 & $95^{\star *}$ & 20 & $22^{* *}$ \\
\hline 6. Run business from work & 89 & $90^{\star *}$ & 25 & $20^{*}$ \\
\hline 7. Ask for a bribe & 98 & 99 & 14 & 11 \\
\hline 8. Take small items from work & 90 & 93 & 40 & 29 \\
\hline 9. Stay away from school on Fridays & 90 & $85^{\star *}$ & 9 & 7 \\
\hline 10. Donate to political party & 72 & 74 & 29 & 27 \\
\hline
\end{tabular}

${ }^{*} p<0.05,{ }^{* *} p<0.01$

Both Tables 3 and 4 reveal apparent anomalies indicative of dissonance. Thus males are at least as likely as females to report paying a politician as corruption but are more likely to engage in it. Similarly Africans are more likely than Indians to regard absenteeism from work as corruption but are at least as likely to do it. This evident lack of accord between beliefs and actions may seem puzzling at first sight but similar results have been found elsewhere. For example, Miller's (2006) study in four post-communist European countries found that the vast majority of citizens and public officials condemned bribery. At the same time, significant minorities (and majorities in some contexts) admitted asking for bribes and to paying bribes. That is, external pressures outweighed inner values, leading officials to 
respond to temptation and citizens to extortion. Miller interprets this to mean that people are best viewed as corruptible rather than as corrupt.

\subsection{Implications of the study's findings for South African anti-corruption measures}

South Africa's present anti-corruption approach relies, ostensibly, on a partnership between government, business and civil society (Ramsingh \& Dobie, 2006). Olken (2007) argues that accurate citizen perceptions of corruption are essential for the political process to restrain corrupt activity effectively. He notes that if individuals' beliefs about corruption inform their decisions about how actively to monitor public officials then biases in these beliefs may affect their monitoring behaviour. Individuals' beliefs may thus, indirectly, impact on corruption control. Any programme aimed at mobilising mass public opinion, whether formal or informal, must be sensitive to factors that may condition popular corruption perceptions.

This study's findings that virtually all (97.1 per cent) respondents consider corruption to be at least a serious domestic issue, and that 79 per cent of respondents believe that corruption levels increased since 2007, suggest that important sections of society are sensitive to the issue and may thus be receptive to being more actively engaged in resisting it. These findings suggest that the National Planning Commission's call to place greater emphasis on preventing corruption through public education drives (2011b) may prove fruitful. Indeed, the recent withdrawal (if only temporary) of the proposed Protection of Information Bill (Underhill \& Donnelly, 2011) and the decision to reopen the investigation into the country's controversial arms deal (Bauer, 2011) signal important victories forced by civil society.

The findings of this study also indicate that there appears to be broad consensus as to what constitutes corrupt behaviour although certain acts may be regarded as more corrupt than others. It seems, furthermore, that respondents, despite evidence of some dissonance, are generally willing to be judged by their own standards. At least some of the lack of agreement between respondents' beliefs and likely actions may be accounted for by the influences of gender and ethnicity. The study offers evidence that males, even though they may recognise corrupt behaviour, are more likely than females to engage in such acts. Similarly, different race groups are evidently more likely to risk particular types of questionable behaviour even if they recognise it as such. These are challenges that appeals to civil society to join in the fight against corruption, whether formally through training programmes or informally, will have to address.

\section{5}

\section{Limitations of the study}

The case approach employed in this study suggests that its findings are not generalisable with any degree of confidence beyond the 2010 population of first and second-year economics and business students registered at the DUT (Pietermaritzburg) and UKZN (Durban) campuses. Future studies could examine aspects of local public sector corrupttion using larger samples at, or across, higher education institutions. Such studies could also explore, more minutely, the prospects of incorporating ethics and anticorruption modules into credit bearing courses.

\section{6}

\section{Conclusion}

This study set out to gauge the perceptions that first and second-year economics and business/ administration Durban University of Technology and UKZN students have of aspects of local public sector corruption and to assess the implications of these perceptions for the local fight against graft. The study was inspired by the proposition that South Africa's present anti-corruption approach (informed primarily by a mix of principal-agent theory and institutional perspectives) needs to be reinforced with comprehensive civic awareness initiatives as recommended in the CCAR.

The study's findings that respondents, overwhelmingly, considered corruption to be a serious problem suggests that potentially influential sections of society may be willing partners in the fight against local public sector 
graft. It seems, furthermore, that the notions that respondents - regardless of gender, ethnicity and religious beliefs - have of what constitutes ethical and moral behaviour are in fact not highly variable so that initiatives to build on society's common ethical core should yield some return. Indeed, evidence of some mismatch between respondents' beliefs and actions suggests a need to align these, possibly by means of formal ethics and integrity schooling programmes.

Since individuals' views and opinions are significantly influenced by schooling it may be worth considering the prospects of introducing ethics and anticorruption education at all stages of formal education, that is, primary, secondary and tertiary levels. Such programmes, if they are to be effective, may need to be particularly sensitive to issues relating to gender and ethnicity. Efforts to introduce integrity training at an early age could serve to consolidate lasting belief in the value of ethical conduct and good governance and would naturally strengthen civil society's role in the local anti-corruption compact.

\section{References}

ANDVIG, J.C., FJELSTAD O., AMUNDSEN I., SISSENER T. \& SOREIDE T. 2000. Bergen/Oslo: Chr. Michelsen Institute (CMI) and Norwegain Institute of International Affairs (NUPI). Available at: www.icgg.org/downloads/contribution07_andvig.pdf [accessed 2011-04-14].

ANON. 2003. Country corruption assessment report, Department of Public Service and Administration, Government of the Republic of South Africa and the United Nations Office on Drugs and Crime. Available at: www.info.gov.za/otherdocs/2003/corruption.pdf [accessed 2011-04-14].

ANON. 2008. Jackie Selebi charged with corruption. News24.com. Available at: http://www.news24.com/ Content/SouthAfrica/News/1059/8922b95b089c41049277c3b72ec [accessed 2010-02-02].

ANON. 2010a. Corruption perceptions index 2010, Transparency International. Available at: http://www.transparency.org/policy_research/surveys_indices/cpi/2010/results [accessed 2011-05-06].

ANON. 2010b. Minister's wife in drug bust. Weekend Witness, 30 January:3.

ANON. 2011. Africa: Universities are training active citizens. Available at: http://www.universityworldnews. com/article.php?story=20110501092449765 [accessed 2011-06-20].

AYOOB, Z. 2003. Health scam: guilty on 339 charges. Natal Witness, 20 November:1.

BAQWA, S. 1999. The problems of organised crime, corruption and fraud in South Africa. In The money laundering regime: policemen or bankers? Sandton, Johannesburg: Arthur Andersen.

BAUER, C. 2000. Public sector corruption and its control in South Africa. In Hope, K.R. \& Chikulo, B.C. (eds.) Corruption and development in Africa: Lessons from country case studies. Palgrave:218.

BAUER, N. 2011. Arms deal investigation: too little, too late? Mail \& Guardian Online. Available at: http://mg.co.za/article/2011-09-15-isnt-it-a-bit-late-for-call-to-arms-mr-president [accessed 2011-09-22].

BOWMAN, D.M. \& GILLIGAN, G. 2008. Australian women and corruption: the gender dimension in perceptions of corruption. JOAAG, 3(1):1-9.

CAMERER, L. 2001. Corruption in South Africa: results of an expert panel survey. Available at: http://www.iss.co.za/Pubs/Monographs/No65/Contents.html [accessed 2011-05-05].

CARTIER-BRESSON, J. 2000. Economics of corruption. Observer, 220, April:25-27.

DOIG, A. \& RILEY, S. 1998. Corruption and anti corruption strategies: issues and case studies from developing countries. In Cheema, G.S. \& Bonvin, J. (eds.) Corruption and integrity improvement initiatives in developing countries. Paris: OECD. Available at: http://www.undp.org/oslocentre/PAR_Bergen_2002/ corruption.htm [accessed 2011-04-29].

GETZ, K.A. \& VOLKEMA, R.J. 2001. Culture, perceived corruption and economics: a model of predictors and outcomes. Business and Society, 40(1):7-30.

HAFFEJEE, F. 2001. Cadres Cash In. Financial Mail, 4 May:30.

HARTLEY, A. 2009. South Africa World Cup 2010... and the shooting's already started. MailOnline. Available at: http://www.dailymail.co.uk/home/moslive/article-1192088/South-Africa-World-Cup-2010-shootings-started.html [accessed 2011-05-05]. 
HENNING, E. VAN RENSBURG, W. \& SMIT, B. 2004. Finding your way in qualitative research, Van Schaik.

HOGG, A. 2011. Not enough canaries in SA's toxic mine. Weekend Witness, 6 August16.

HUSTED, B.W. 1999. Wealth, culture and corruption. Journal of International Business Studies, 30(2): 339-360.

IRISH, J. 2003. The structure and modus operandi of organised crime groups in SA. Available at: http://www.iss.co.za/pubs/monographs/No77/Content.html [accessed 2011-05-05].

KAUNDA, L. 2001. I-Afrika entsha initiative is a beacon of hope. Natal Witness, 7 November p.9.

LAMBSDORFF, J.G. 1999. Corruption in empirical research - a review. Available at: gwdu05.gwdg.de/ $\sim$ uwvw/downloads/contribution05_lambsdorff.pdf [accessed 2011-04-18].

LANDMAN, W. 2000. Tackling SA's ethics crisis. Financial Mail, 28 July:40.

LUND, T. 2010. Tenderpreneurs: a legal free for all. Finweek, 18 March:16-22.

MAKHANYA, A. 2003. A nation on trial. Mail \& Guardian, 1 August:2.

MILLER, W.L. 2006. Corruption and corruptibility. World Development, 34(2):371-380.

MTHOMBOTHI, B. 2000. Supping with Satan. Financial Mail, 23 June:16.

NATIONAL PLANNING COMMISSION, 2011a. Diagnostic overview, Pretoria: Department of the Presidency. Available at: http://www.info.gov.za/view/DownloadFileAction?id=147192 [accessed 2011-11-16].

NATIONAL PLANNING COMMISSION, 2011b. National development plan vision for 2030, Pretoria: Department of the Presidency. Available at: http://www.npconline.co.za/medialib/downloads/home/ NPC\%20National\%20Development\%20Plan\%20Vision\%202030\%20-lo-res.pdf [accessed 2011-11-16]. NYE, J.S. 1967. Corruption and development: a cost benefit analysis. American Political Science Review, 1967(LXI):417-427.

OLKEN, B.A. 2007. Corruption perceptions versus corruption reality. Available at: www.nber.org/ bolken/ corruptionpercep... [accessed 2011-05-06].

PALDAM, M. 2001. Corruption and religion: adding to the economic model. Kyklos, 54:383-414.

RAMSINGH, O. \& DOBIE, K. 2006. Lessons learnt on anti-corruption: case study on the South African national anti-corruption forum. Available at: http://www.nacf.org.za/lessons-learnt/index.html [accessed 2011-05-06].

RAUCH, J. 2005. Linking crime and morality: reviewing the moral regeneration movement. SA Crime Quarterly, 11. Available at: http://www.iss.co.za/pubs/CrimeQ/No.11/Contents.htm [accessed 2011-05-06].

RAUTENBACH, F. 2000. The real risk, Mr President. Financial Mail, 2 June:16.

RAZAFRINDRAKOTO, M. \& ROUBAUD, F. 2003. Wages and corruption: the case of Madagascar, Profile Books.

RILEY, S.P. 1998. The political economy of anti-corruption strategies in Africa. European Journal of Development Research, 10(1:129-159.

SHAW, M. 1998. Organised crime in post-apartheid South Africa. Available at: http://www.iss.co.za/pubs/ Papers/28/Paper28.html [accessed 2011-05-05].

SPENCER, S. 2001. We should embrace honour and duty. Mail \& Guardian, 26 October:43.

UNDERHILL, G. \& DONNELLY, L. 2011. NEC members deny prompting halt of Secrecy Bill. Mail and Guardian Online. Available at: http://mg.co.za/article/2011-09-23-nec-members-deny-prompting-halt-ofsecrecy-bill/ [accessed 2011-09-23].

VAN DER MERWE, A.D. 2004. Public sector corruption: the perceptions of KwaZulu-Natal public sector managers and anti-corruption agents. Unpublished Masters Thesis. Durban: University of KwaZulu-Natal.

VAN DER MERWE, A.D. 2006. The nature and causes of corruption: the perceptions of KZN public service managers and anti-corruption agents. Journal of Public Administration, 41(1):32-46.

WOODS, G. 2011. An inside job. Delivery, (April-June 2011):28-30.

ZUMA, J. 2009. State of the Nation Address 2009. Available at: http://www.info.gov.za/speeches/2009/ 09060310551001.htm [accessed 2011-04-27].

ZUMA, J. 2010. State of the Nation Address 2010. Available at: http://www.info.gov.za/speeches/2010/ 10021119051001.htm [accessed 2011-04-27]. 